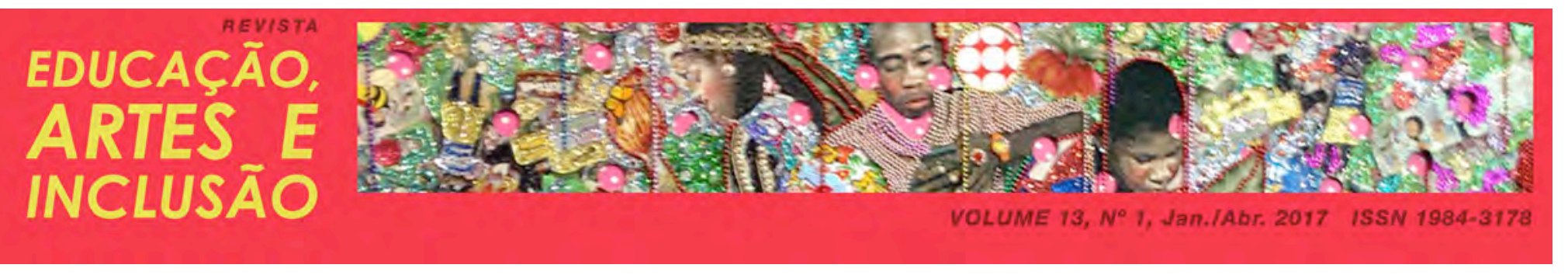

\title{
PERMANÊNCIAS DO MODELO MÉDICO NOS DISCURSOS DOS PROFESSORES DA EDUCAÇÃO ESPECIAL
}

\section{PERMANENCES OF THE MEDICAL MODEL IN THE SPEECHES OF SPECIAL EDUCATION TEACHERS}

DOI: $\underline{\text { http://dx.doi.org/10.5965/1984317813012017141 }}$

Renata Maldonado Silva, Luana Leal Ribeiro - UENF

\begin{abstract}
RESUMO
A interferência da medicina na educação especial acontece desde seu surgimento e ainda pode ser encontrada por meio da solicitação do laudo médico como comprovante de deficiência para efetivação da matrícula de alunos público-alvo dessa modalidade educacional no atendimento especializado. Assim, o presente estudo teve por objetivo identificar de que modo o instrumento do laudo é utilizado nas práticas pedagógicas dos professores que atuam com a modalidade especial. Com esse objetivo, foram realizadas entrevistas semiestruturadas com sete docentes, nas quais cinco dessas atuam no Atendimento Educacional Especializado - AEE e duas na sala regular, mas que possuem alunos da educação especial como seus discentes. Diante da análise de conteúdo das entrevistas, por meio da categorização do discurso produzido, foi possível apreender que os profissionais da educação aceitam, com baixa problematização, o saber advindo dos profissionais da medicina, ao exaltarem o diagnóstico clínico como primordial para sua prática com alunos público-alvo da educação especial. Porém, apesar desse discurso hegemônico, compreendeu-se que de fato o laudo médico não exerceu função estratégica nas práticas pedagógicas desenvolvidas pelas professoras, servindo, primordialmente, como respaldo para o nulo ou baixo desenvolvimento dos alunos que apresentam peculiaridades em seu processo de ensino-aprendizagem.
\end{abstract}

Palavras-chave: Educação especial. Modelo médico de compreensão da deficiência. Laudo médico.

\begin{abstract}
The interference of medicine in special education has been occurring since its inception and can still be found by requesting the medical report as proof of disability to effect the enrollment of students targeted to this educational modality in specialized care. Thus, the present study aimed to identify how the instrument of the report is used in the pedagogical practices of teachers who work with the special modality. With this objective, semi-structured interviews were carried out with seven teachers, in which five of these work in the Specialized Educational Service and two in the regular classroom. Given the content analysis of the interviews, through the categorization of the discourse produced, it was possible to perceive that the professionals of education accept, with low problematization, the knowledge coming from the medical professionals, while extolling the clinical diagnosis as primordial for their practice with students Target audience for special education. However, in spite of this hegemonic discourse, it was understood that in fact the medical report did not exercise a strategic function in the pedagogical practices developed by the teachers, serving, primarily, as support for the null or low development of the students who present peculiarities in their teaching- learning.
\end{abstract}

Keywords: Special Education. Medical Model of disability. Medical report. 


\section{INTRODUÇÃO}

A discussão sobre a efetivação do direito à escolarização de pessoas com deficiência é muito recente em nossa sociedade, com a intensificação dos debates acerca dessa questão somente nas décadas finais do século XX. Nesse contexto, no decorrer da história, a educação especial foi sendo desenvolvida como uma forma de escolarização para pessoas que fizessem parte de um determinado grupo, atualmente caracterizado, por alunos com deficiência, transtornos globais do desenvolvimento e alunos com altas habilidades/superdotação.

A educação especial é uma modalidade de ensino transversal a todos os níveis e etapas, da educação básica (educação infantil, ensino fundamental, ensino médio) à educação superior, assim como a todas as modalidades (educação de jovens e adultos, educação profissional e tecnológica, educação indígena, educação do campo). Em todos esses níveis, etapas e modalidades, é ofertado o Atendimento Educacional Especializado - AEE que tem como função identificar, elaborar e organizar recursos pedagógicos e de acessibilidade que possibilitem a eliminação de entraves que limitam a plena participação dos alunos no ambiente escolar, considerando suas necessidades específicas. As atividades desenvolvidas no AEE são diferenciadas das que se realizam na sala de aula comum, sendo importante ressaltar que não são substitutivas à escolarização. Nesse sentido, o AEE desempenha o papel de complementar e/ou suplementar a formação dos alunos ao visar à autonomia e a independência na escola e fora dela (BRASIL, 2008).

Basicamente, pode-se considerar que o público-alvo da educação especial vivenciou, historicamente, quatro períodos específicos: em um primeiro momento, até o século $\mathrm{XV}$, durante o período da Idade Média e o início da Modernidade, experimentou um contexto de exclusão, pois era mantido fora do convívio social, recluso no ambiente doméstico. Isso porque naquela época acreditava-se que as pessoas com deficiência seriam criaturas malignas, tudo isso porque não eram compatíveis com o estereótipo daquelas sociedades. Posteriormente, a partir da Idade Moderna, passaram a ser segregadas em instituições exclusivamente voltadas para esse tipo de atendimento, que eram vinculadas às ações filantrópicas, muitas delas gerenciadas pela Igreja Católica, com parcas ofertas de escolarização. Em um terceiro momento, somente no século $\mathrm{XX}$, esse público passou a frequentar as escolas regulares através das classes especiais, em uma perspectiva de integração, porém, permanecendo o contexto de segregação, uma vez que os alunos das 
classes especiais vivenciavam a escolarização em um ambiente separado dos demais. A última fase é a da inclusão social, constituindo-se como um movimento que ganhou expressividade especificamente a partir dos anos 1980 e que, consequentemente, promoveu o movimento da inclusão escolar.

Em todos esses momentos houve a influência de profissionais das ciências da saúde, que interferiam, em menor ou maior grau de acordo com sua especialidade. A medicina teve destaque nesse processo, não somente no tratamento despendido às pessoas que apresentavam alguma anomalia, mas também passou a interferir na maneira em que eram ofertadas ações de escolarização a esse público. Não por acaso, estas emergiram de experiências elaboradas por médicos, que despertaram o interesse sobre a necessidade de escolarizar indivíduos com deficiência que, em sua maioria, habitavam hospitais psiquiátricos, sem distinção de patologia ou idade, principalmente nos casos de deficiência mental. A partir desse enfoque médico, a deficiência passou a ser entendida como uma doença crônica devendo seu atendimento, até mesmo pela vertente educacional, ser ofertado pelo viés terapêutico (GLAT; PLETSCH; FONTES, 2007).

Mesmo com o avanço das práticas escolares voltadas para o público-alvo da modalidade especial, ainda pode ser possível identificar traços de interferência do modelo médico de compreensão da deficiência nesse âmbito. Neste, o diagnóstico clínico ainda é considerado como importante instrumento no encaminhamento desses alunos à modalidade citada, principalmente ao AEE. Apesar de haver orientação do Ministério da Educação MEC de que o diagnóstico não pode ser considerado imprescindível para efetivação desse atendimento, esse instrumento ainda é solicitado como forma de comprovação de que o aluno faz parte do público-alvo a ser atingido pela educação especial no Brasil.

Destarte, o presente estudo teve origem a partir da possibilidade de que a oferta de escolarização para o público-alvo da educação especial no município de Campos dos Goytacazes/RJ ainda estaria vinculada ao modelo médico de compreensão da deficiência, tudo isso com base na solicitação formal do laudo médico para matrícula dessas pessoas no AEE. Com esse objetivo, foram realizadas entrevistas semiestruturadas com profissionais que atuam na modalidade de educação especial para identificar a real aplicabilidade que o laudo clínico exerce no fazer profissional desses atores. 


\section{INFLUÊNCIAS DO MODELO MÉDICO DE COMPREENSÃO DA DEFICIÊNCIA NA EDUCAÇÃO ESPECIAL}

Antes da percepção da deficiência como uma característica biológica dos indivíduos, as pessoas que apresentavam algum tipo de anomalia eram percebidas por concepções místicas vinculadas a crenças da Igreja católica, de que esses sujeitos seriam "provas da ira de Deus”. A partir do gradativo rompimento com antigas crenças supersticiosas ou mágicas, o conceito de verdade, que antes pertencia aos que discorriam em nome de um ser superior, deslocou-se para a ciência, ocasionando em profundas modificações sobre significados e ações voltadas para as pessoas com deficiência. As mudanças tiveram início no momento em que a deficiência foi atribuída a uma questão biológica, propagada pelos critérios de racionalidade construídos pelas sociedades ocidentais, que representavam o saber dominante em termos médicos (PICCOLO, 2012).

Nesse contexto, no período da Idade Média surgiu o modelo médico individual de deficiência, que consistiu em um conjunto de pressupostos e conhecimentos advindos das ciências da saúde, que passou a tratar a deficiência como um desvio do que poderia ser considerado normal, de acordo com padrões bio-fisiológicos. A partir de então, a deficiência adquiriu um status de falha, limitação e incapacidade, sendo explicadas nos séculos seguintes segundo as diretrizes da biologia, indústria, estatística e medicina, surgindo então, o indivíduo deficiente (PICCOLO, 2012).

Foucault (2000) afirmou que com o avanço da biologia, os sujeitos passaram a ser considerados como seres que possuíam funções e

que recebe estímulos (fisiológicos, mas também sociais, inter-humanos, culturais), que responde a eles, que se adapta, evolui, submete-se às exigências do meio, harmoniza-se com as modificações que ele impõe, busca apagar os desequilíbrios, age segundo regularidades, tem em suma, condições de existência e a possibilidade de encontrar normas médias de ajustamento que lhe permitem exercer suas funções (FOUCAULT, 2000, p. 494). 
Com a disseminação dessa lógica, juntamente com a consolidação do sistema capitalista, foram criados mecanismos a fim de demarcar a norma através de um rigoroso processo de instrumentação técnica. Assim, o que foge à norma não é o diferente, mas sim, o desprezável, o que deveria ser evitado. Portanto, a norma configurou-se, mais do que um definidor, mas também, como um elemento de segregação, estabelecendo a diferença e a classificação posteriormente, como de menor valia. A partir dessa concepção, conceituou-se que a deficiência nas sociedades modernas, visto como um problema individual, somente deveria ser remediada através de ações clínicas e terapêuticas (PICCOLO, 2012).

A partir do discurso da descoberta das origens da deficiência, deu-se início ao período de medicalização ${ }^{1}$, com base na associação das causas naturais vinculadas à formação orgânica dos indivíduos. Posteriormente, o avanço do capitalismo contribuiu para a disseminação da medicalização, pois, por meio dos tratamentos clínicos com pouca ênfase em ações pedagógicas, visava-se adequar as pessoas com deficiência às atividades exigidas pelo sistema de produção (PADILHA, 2014).

Pessotti (2012) indicou o final do século XVIII como marco inicial do atendimento educacional às pessoas com deficiência. Isto ocorreu por meio da criação de instituições especializadas para surdos e cegos, ao oferecer escolarização aos que eram impedidos de usufruírem do ensino regular, que também era restrito para a população no geral nessa época. Com isso, é possível afirmar que as deficiências sensoriais inauguraram o processo de intervenções educacionais específicas, mesmo que em forma de iniciativas isoladas e sem estruturação pedagógica. Nesse caso, um dos seus principais objetivos era a socialização desses indivíduos.

A expansão da rede de hospitais psiquiátricos e asilos designados para a permanência de pessoas com deficiência, entre os séculos XVIII e XIX, evidenciou a desobrigação do Estado em relação à disponibilização de serviços educacionais para esse público. Porém, essas instituições despendiam altos custos de manutenção, acarretando em que a educação passasse a ser considerada uma alternativa financeiramente viável. Nesse caso, as escolas especiais passaram a se adequar aos interesses estatais ao promoverem uma educação voltada à

\footnotetext{
${ }^{1}$ Moysés (2010) apresenta a medicalização como uma transformação artificial de questões que não eram do âmbito da medicina, em problemas médicos. A mesma argumentou que nesse contexto, as questões coletivas são tomadas como individuais e os problemas sociais e políticos, como biológicos.
} 
reabilitação e à adaptação à vida em sociedade das pessoas consideradas "anormais", prosseguindo com a desobrigação do sistema educacional pela inclusão de todas as pessoas (PADILHA, 2014).

Especificamente no Brasil, o marco inicial na oferta de escolarização para pessoas com deficiência também ocorreu primeiramente para as sensoriais, ainda no período imperial, com a criação de institutos para alunos com deficiência visual e auditiva. Mesmo com a criação dessas instituições de atendimento especializado, ficou evidente que o processo de medicalização da deficiência, que já vinha ocorrendo na Europa desde o século XVIII, ganhou expressão no país. Isto porque os hospitais continuavam a receber um expressivo quantitativo de pessoas com deficiência, especialmente, mental, considerados como doentes, sem perspectiva de aprendizagem (PADILHA, 2014).

Somente no início do século XX os médicos passaram a reconhecer a importância da pedagogia no momento em que perceberam que os tratamentos exclusivamente terapêuticos ofertados para pessoas com deficiência, que apresentavam casos mais graves, não estavam obtendo resultados satisfatórios. Com isso, os profissionais da medicina no Brasil fundaram instituições escolares ligadas aos hospitais psiquiátricos, denominados pavilhões. Nesses locais, era mantida a segregação por meio da categorização de anormalidade, separando-os em anormais intelectuais, morais e pedagógicos (JANUZZI, 2012).

Nas primeiras décadas do século XX, no Brasil, a iniciativa privada ofertava majoritariamente os serviços previstos para educação especial, através de financiamento público, surgindo institutos, associações e fundações sem fins lucrativos. Esse fato dificultou o acesso ao sistema educacional, pelo fato das instituições privadas ganharem notoriedade pela prestação de serviços educacionais, médicos e assistenciais, fortalecendo a desobrigação estatal no quesito educacional (PADILHA, 2014).

A educação especial, que até então foi construída a partir de uma compreensão da deficiência pautada nos preceitos da Medicina e da Psicologia, passou a sofrer intervenções, buscando retirar a hegemonia discursiva das ciências da saúde. Portanto, passaram a ser difundidas as teorias da Sociologia e da Antropologia, que promoveram especial contribuição nestas discussões (HARLOS, 2012). 
3 MUDANÇA NO PARADIGMA MÉDICO DE COMPREENSÃO DA DEFICIÊNCIA E INFLUÊNCIA NA EDUCAÇÃO ESPECIAL

Em meados do século XX surgiram em diversos países, questionamentos e movimentos em prol da modificação do paradigma médico de compreensão da deficiência, levantando discussões acerca da necessidade da incorporação da sociedade no tratamento das questões vivenciadas pelo público que possuía especificidades em relação aos "normais". Assim, a deficiência não deveria ser entendida como um problema individual, mas sim como uma questão social. Portanto, deveria ser retirada a responsabilidade do indivíduo pela opressão vivenciada por pessoas com deficiência e transferir "para a incapacidade social em prever e incorporar a diversidade" (DINIZ, 2007, p. 15).

Com a efervescência das discussões sobre a necessidade de abolir o paradigma médico e o repasse do problema da deficiência do indivíduo para sociedade, por meio do discurso que a estrutura social criava a deficiência pela falta de serviços e oportunidades adequadas que assegurassem a participação desse público em todas as esferas da sociedade, o debate sobre a educação também ganhou notoriedade. Embora os teóricos vinculados à sociologia da deficiência reconhecessem a importância da educação especial, estes passaram a manifestar interpretações contrárias às práticas pedagógicas que vinham sendo realizadas nessa modalidade de ensino, principalmente, as que aconteciam em ambientes segregados do ensino regular em escolas e classes especiais.

No âmbito educacional, até a década de 1970, os serviços da modalidade especial eram ofertados para crianças e jovens que eram impedidos de acessar a escola comum ou para os que não conseguiam avançar no processo educacional, configurando o caráter segregacionista imposto a educação especial. Isto ocorria em função da maioria da sociedade considerar como adequado que esse alunado tivesse suas necessidades educacionais melhores atendidas, o que acarretou em que a educação especial se constituísse como um sistema paralelo ao sistema educacional geral (MENDES, 2006). Na tentativa de sensibilização da sociedade acerca dos prejuízos da marginalização, a segregação passou a ser uma prática intolerável, incidindo também a que era exercida no contexto escolar. A partir da intensificação desse debate, foram criadas propostas de um novo modelo escolar, no qual todas as crianças com deficiência teriam o direito de frequentar os espaços e atividades que as demais crianças frequentavam. 


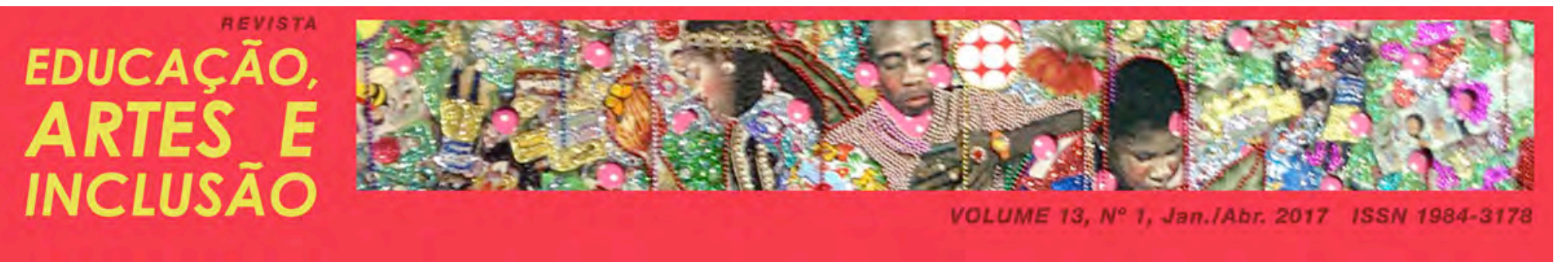

Nesse contexto, surgiram fundamentos de práticas integradoras em relação à escolarização, com a perspectiva de que as pessoas com deficiência teriam a oportunidade de

participar de ambientes de aprendizagem mais desafiadores; ter mais oportunidades para observar e aprender com alunos mais competentes; viver em contextos mais normalizantes e realistas para promover aprendizagens significativas; e ambientes sociais mais facilitadores e responsivos (MENDES, 2006, p. 388).

A proposta baseou-se em que esses alunos passassem a vivenciar experiências consideradas mais próximas da 'normalidade'. De forma abrangente, o modelo de integração pregava a preparação prévia dos alunos que apresentavam necessidades educacionais especiais para que eles pudessem ter condições de acompanhar a turma no ensino regular, usufruindo de apoio especializado paralelo. Com esse fato, manteve-se a concepção do modelo médico de deficiência, ao centrar o problema nos alunos, sem a responsabilização da escola. Esta ficava encarregada somente de escolarizar os que tinham condições de acompanhar as atividades regulares, sem preocupação com as especificidades dos demais (PLETSCH, 2010).

O modelo de integração escolar passou a ser criticado por buscar a inserção formal dos alunos com deficiência na mesma escola, sem que obrigatoriamente, estes frequentassem as atividades da classe comum. Em função do debate acima citado, os ideais de normalização e integração começaram a perder força. Isto deu início a uma intensificação de discussões que colocavam as pessoas com deficiência como cidadãos comuns, detentores dos mesmos direitos e que poderiam usufruir das oportunidades disponíveis na sociedade. Caberia à sociedade se reorganizar para garantir o acesso universal a todos os serviços e espaços, independente do grau de proximidade com a normalidade, dando início ao movimento de inclusão social (ARANHA, 2001).

Com esse movimento, a partir da década de 1980, as propostas de práticas inclusivas passaram a ser desenvolvidas com o principal objetivo de eliminar as barreiras que excluíam as pessoas com deficiência e que as mantinham afastadas das atividades e instituições sociais. No âmbito educacional, foram criados projeto para que as escolas fossem reestruturadas, tanto no seu espaço físico, que deveriam sofrer alterações para atender as demandas das pessoas 
com deficiência física, mas também, no processo de pensar em formas de promover a aprendizagem das pessoas com deficiência intelectual nas classes regulares (LOURENÇO, 2010).

Somente no ano 2001, no Brasil foram lançadas as Diretrizes Nacionais para Educação Especial na Educação Básica, pela Resolução no 2/2001 da Câmara de Educação Básica do Conselho Nacional de Educação. Esse documento, no plano discursivo, marcou um avanço em relação ao que vinha sendo feito para educação especial, ao instituir pela primeira vez o termo "educação inclusiva" para nortear as ações governamentais realizadas a partir de então, mesmo que as políticas públicas continuassem sendo elaboradas e implementadas sobre a perspectiva da integração.

As Diretrizes Nacionais para Educação Especial na Educação Básica (2001) oficializaram o termo "necessidades educacionais especiais" e passou a regulamentar o modo de organização e a função da educação especial nos sistemas de ensino que englobavam a educação básica. Além disso, determinou os locais de atendimento e as propostas de flexibilização e adaptação curricular (PLETSCH, 2010). De acordo com Garcia (2006), a inserção do conceito de necessidades educacionais especiais no texto legal pode ser entendida como uma tentativa de superação do modelo de compreensão e das práticas relacionadas à educação especial pautados no modelo médico-psicológico. Portanto, essa conceituação teria por objetivo a retirada do foco nos diagnósticos de deficiência, priorizando as necessidades de aprendizagem. Isso ficou explícito nas Diretrizes anteriormente citadas, que conceituou as necessidades educacionais especiais como um conceito amplo e que

em vez de focalizar a deficiência da pessoa, enfatiza o ensino e a escola, bem como as formas e condições de aprendizagem; em vez de procurar, no aluno, a origem de um problema, define-se pelo tipo de resposta educativa e de recursos e apoios que a escola deve proporcionar-lhe para que obtenha sucesso escolar; por fim, em vez de pressupor que o aluno deva ajustar-se a padrões de "normalidade" para aprender, aponta para a escola o desafio de ajustar-se para atender à diversidade de seus alunos (BRASIL, 2001, p. 33).

Esse conceito "inaugurou" a possibilidade de superação do fazer pedagógico tradicional por trabalhar em uma perspectiva da inclusão no âmbito da educação especial, ampliando a sua ação (GARCIA, 2006). Essa afirmação teria por base o trecho das Diretrizes 
que afirma que essa modalidade educacional passaria a focalizar não somente as dificuldades de aprendizagem vinculadas às condições dos alunos seja por limitações e/ou deficiência. Entretanto, deveriam ser aceitos como público-alvo da educação especial os, alunos que apresentassem "dificuldades cognitivas, psicomotoras e de comportamento" (BRASIL, 2001, p. 44), mesmo sem vínculo a uma causa orgânica específica.

Cabe ressaltar que após a divulgação dessa normativa, várias outras foram lançadas ressaltando a importância da constituição de uma política educacional inclusiva. Entretanto, não faziam menção de que a educação especial deveria ser atrelada a conhecimentos do âmbito das ciências da saúde, mesmo restringindo o público-alvo da educação especial para os alunos que possuíssem deficiência, transtornos globais do desenvolvimento e altas habilidades/superdotação. Porém, essa questão pode ser indagada no momento em que se tem conhecimento que o laudo médico é utilizado como comprovante da necessidade especial do aluno no ato da matrícula deste no Atendimento Educacional Especializado - AEE. Esse processo foi identificado no município de Campos dos Goytacazes/RJ, onde se levantou a hipótese que apesar de solicitado, o instrumento médico não servia como elemento base para criação de estratégias pedagógicas nas práticas dos professores que atuam com alunos que fazem parte do público-alvo da educação especial, o que será desenvolvido no próximo item.

\section{EXPRESSÕES DO MODELO MÉdICO NA EDUCAÇÃO ESPECIAL: UMA EXPERIÊNCIA NO MUNICÍPIO DE CAMPOS DOS GOYTACAZES/RJ}

O saber advindo das ciências da saúde, como já foi ressaltado, se configurou como imperativo na oferta de tratamento e ações despendidas às pessoas com deficiência ao longo da história. A partir do momento em que esses profissionais passaram a intervir na escolarização dessas pessoas, o diagnóstico configurou-se imprescindível, como uma possível forma de prever as ações mais adequadas de acordo com a situação clínica-psicológica dos alunos. Esse fato inaugurou um discurso que ainda permeia o cenário educacional, que busca justificar o "fracasso escolar" com base na "patologização" das dificuldades que alunos apresentam em seu processo de ensino-aprendizagem. No momento em que alunos demonstram essas dificuldades, temos presenciado ações que responsabilizam o âmbito da medicina como detentor do melhor tratamento para sanar as questões apresentadas. 


\subsection{MEDICALIZAÇÃO, PATOLOGIZAÇÃO E O USO DO LAUDO MÉDICO NA VIDA ESCOLAR DE ALUNOS PÚBLICO-ALVO DA EDUCAÇÃO ESPECIAL}

Muitas vezes, as dificuldades de aprendizagem enfrentadas por alunos são compreendidas como consequências de uma doença, fazendo girar, o que Garrido (2010, p. 1) classificou como "grande engrenagem de encaminhamentos da escola a especialistas da área de saúde". Como dissertou a autora, diante dos problemas de aprendizagem enfrentados pelos alunos e seus responsáveis, o diagnóstico responde angústias de familiares e professores, que desconsideram a própria participação no fracasso da vida escolar dos alunos. A partir da produção do diagnóstico, entram em cena, na maioria das vezes, medicamentos que prometem consertar o problema, criando expectativas em relação à cura.

Christofari (2014) indicou que esse fenômeno tende a transformar o problema em uma questão biológica, centrado no indivíduo. Na esfera educacional, relacionou o que não está adequado às normas e o não enquadramento do desenvolvimento escolar a uma suposta causalidade orgânica, direcionando as intervenções na busca de um acompanhamento e controle da possível "doença". Esse discurso tende a produzir crianças incapazes de aprender e com isso, surgiu à necessidade de um tipo de intervenção que deixa de fazer parte do âmbito pedagógico. Esse meio de gerir os processos pedagógicos tem sido considerado como única alternativa para a educação, no qual, patologizar os que a escola não consegue alcançar, faz com que sejam criadas demandas dirigidas aos serviços de saúde. Christofari (2014) ainda afirmou que esse tipo de intervenção nem sempre é proposto com objetivo final de potencializar a capacidade dos alunos, mas sim, visa transformar o aluno, identificado com base na ideia da anormalidade, em um sujeito mais próximo possível da norma. Assim,

o processo de medicalização tem como um de seus princípios acalmar conflitos. Se o "problema" está no aluno, ninguém tem culpa da sua "doença". O discurso direcionado ao aluno comumente sintetiza: "não é caso para o pedagógico, mas para a saúde" (CHRISTOFARI, 2014, p. 23).

Cabe destacar, que a existência da deficiência e a possibilidade de comprometimento em seu processo cognitivo é real. Porém, a produção e utilização de diagnósticos como justificativa para a falta ou baixo desenvolvimento escolar de alunos, devem ser problematizadas. A solicitação de laudo clínico para encaminhamento de alunos que 


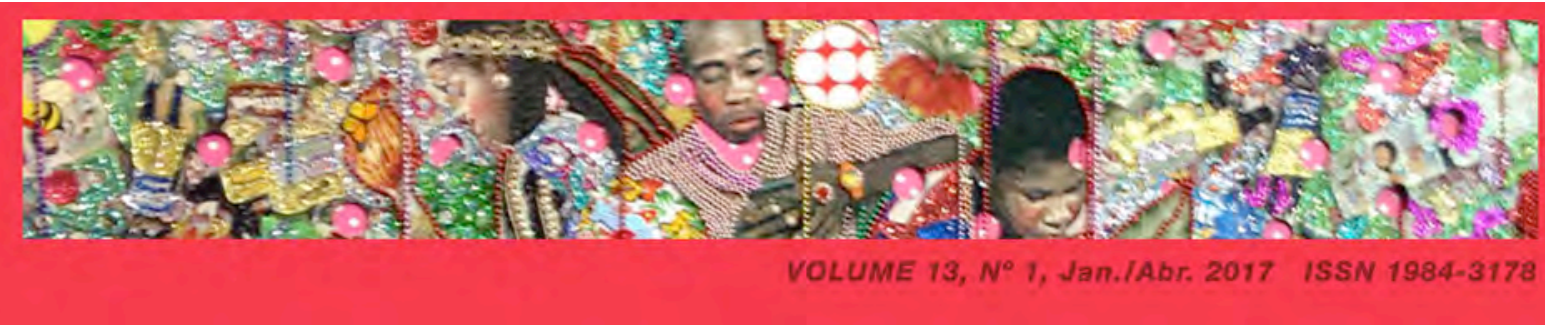

apresentem dificuldades educativas em seu processo de ensino-aprendizagem contribui para que esse alunado seja rotulado a partir de suas especificidades no processo educacional, não oferecendo subsídios para que professores possam desenvolver suas práticas pedagógicas adequadamente (GLAT; PLETSCH, 2011).

Nesse sentido, percebem-se ainda hoje indícios do predomínio do modelo médico de deficiência a partir da exigência que alguns municípios fazem de um laudo médico com a descrição da deficiência, transtorno global do desenvolvimento ou altas habilidades/superdotação, para efetivar a matrícula do aluno com necessidade educacional especial no atendimento educacional especializado. Apesar de não haver normativa expedida pelo Ministério da Educação, em âmbito nacional, que classifique como obrigatória a apresentação do laudo no ato da matrícula, alguns municípios ainda impõem essa obrigatoriedade.

Esse é o caso da rede municipal de educação de Campos dos Goytacazes/RJ, que por meio da resolução/SME $n^{\circ}$ 01/12, de dia 26 de dezembro de 2012, fixou normas para o atendimento a alunos com necessidades educacionais especiais na rede municipal de ensino, ressaltando que, no ato da matrícula, deverá ser solicitado o laudo médico (CAMPOS DOS GOYTACAZES, 2012). Também pela análise do Diário Oficial do Município de Campos dos Goytacazes foi possível identificar nas portarias que estabelecem as normas para matrícula de alunos nas unidades escolares da rede municipal dos anos de 2009 a 2016, a solicitação do laudo clínico aos pais ou responsável legal, e ao próprio aluno, se já atingida à maioridade civil, como um dos documentos necessários na efetivação da matrícula, em se tratando de candidato que necessitar de atendimento educacional especializado. Cabe destacar que a partir do ano de 2015, a portaria que estabeleceu as normas para a matrícula, solicitou o laudo clínico do candidato com necessidades educativas especiais e adicionou que esse documento não seria requisito imediato para a matrícula. A partir disso, a unidade escolar deveria, em parceria com a Diretoria Multiprofissional - sendo esta a responsável pela criação de ações e estratégias no âmbito da educação inclusiva, não somente da modalidade especial acompanhar o aluno.

Apesar de não ser considerado mais requisito imediato, constatou-se que a solicitação do laudo ainda permeia o cenário educacional do município. Assim, com o objetivo de identificar de que modo o instrumento do laudo é utilizado nas práticas pedagógicas dos 
professores que atuam com a modalidade especial, foram realizados procedimentos para contemplar o objetivo proposto.

\subsection{PERCURSOS METODOLÓGICOS, ORGANIZAÇÃO E DISCUSSÃO DOS DADOS}

Visando o desenvolvimento de uma pesquisa que pudesse desvelar a realidade e suas expressões, a partir de fatos reais, considerando, principalmente, a fala dos atores entrevistados, o presente estudo se configurou como empírico de natureza qualitativa, sendo de característica descritiva, no qual os resultados escritos com base nos dados recolhidos durante a investigação contêm citações para ilustrar e substanciar a apresentação dos resultados (BOGDAN, BIKLEN, 1994).

Além da pesquisa bibliográfica, brevemente já apresentada, foi realizada uma pesquisa documental. Segundo Gil (2008) a pesquisa documental parte de dados ainda inexplorados, que não receberam tratamento analítico. Nesse sentido, considerou-se por análise documental, nesta pesquisa, a apreciação de resoluções e portarias municipais da Secretaria Municipal de Educação, Cultura e Esporte - SMECE, Leis e Diários Oficiais do município de Campos dos Goytacazes/RJ, de 2004 a 2016. Tais documentos foram acessados por meio eletrônico, via internet.

Com a finalidade de apreender os conhecimentos, concepções e práticas dos profissionais que atuavam na modalidade de educação especial da rede municipal, foi necessária a criação de estratégias que possibilitassem conhecer suas vivências, assim como suas observações sobre a realidade educacional do município. Para tal, foi escolhido a técnica da entrevista, sendo esta, um encontro entre duas pessoas com o objetivo de obter informações a respeito de determinado assunto, diante de uma conversação de natureza profissional. A entrevista é utilizada na investigação social, na fase da coleta de dados, a fim de ajudar no diagnóstico ou no tratamento de um problema social (MARCONI; LAKATOS, 2003).

Acerca da estruturação, a escolhida foi a entrevista semiestruturada, pois permitiu que o pesquisador pudesse obter dados comparáveis entre os sujeitos que discorrem sobre determinado tema, sem que o entrevistador necessite se deter somente nas questões 
previamente estabelecidas, oportunizando a moldagem do conteúdo no ato da recolha (BOGDAN; BIKLEN, 1994).

A escolha dos atores da presente pesquisa, aconteceu por meio do tipo de amostragem não-probabilística (MARCONI, LAKATOS, 2003), através da técnica “bola de neve”. Nesse caso, o entrevistador estabeleceu contato inicial com alguns sujeitos que foram identificados como membros do grupo que se pretendia estudar, sendo estes, dois funcionários da SMECE, e os mesmo indicaram os primeiros professores entrevistados, que sugeriram os demais, sucessivamente.

Cabe ressaltar, que foi sinalizado no ato das entrevistas que as identidades seriam preservadas, sendo adotados, nomes fictícios no presente trabalho para denominar os participantes da pesquisa. As entrevistas foram realizadas em diferentes ambientes, como na sede da SMECE; em SRMs de quatro escolas, sendo uma entrevista realizada ao mesmo tempo com duas professoras de uma mesma instituição; na sala de aula regular de duas escolas.

Após a coleta dos dados foi realizada a transcrição das entrevistas de forma fidedigna, não sendo inclusive alterados vícios de linguagem reproduzidos pelos sujeitos da pesquisa. Foram então criadas categorias a partir dos objetivos delimitados, considerando que as categorias constituem um meio de classificar os dados descritivos de forma que o material possa ser fisicamente dividido (BOGDAN; BIKLEN, 1994).

Foi utilizada a técnica da análise de conteúdo, sendo esta, um conjunto de técnicas de análise das comunicações em busca de indicadores que possibilitem a inferência de conhecimentos sobre as condições de produção das mensagens, por meios de procedimentos sistemáticos e objetivos de descrição (BARDIN, 1977).

$\mathrm{Na}$ fase da interpretação, buscou-se ir além do material produzido e com base nas inferências, foi possível discutir os resultados da pesquisa de forma mais ampla, procurando atribuir um grau de significação maior aos conteúdos analisados, através da articulação da superfície do texto descrito e problematizando com os fatores que determinam suas características (BARDIN, 1977). Ao final, foram sintetizadas as questões da pesquisa, os resultados obtidos a partir da análise do material coletado e as inferências realizadas, 


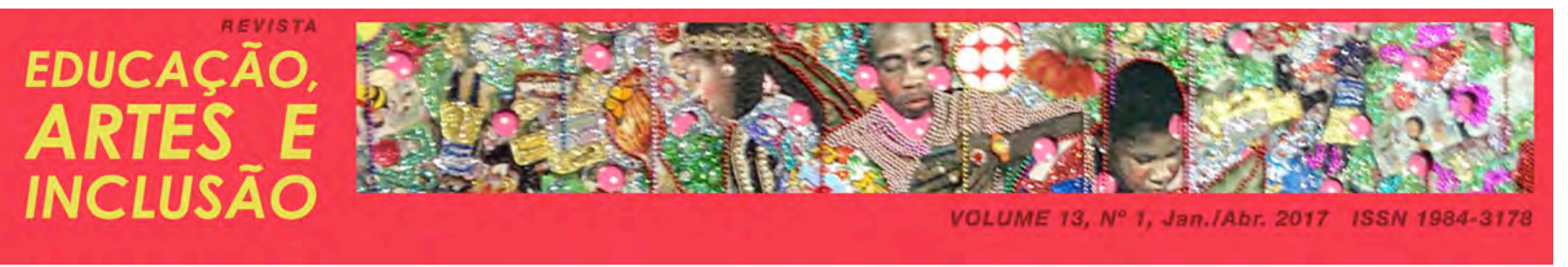

juntamente com a perspectiva teórica adotada, sendo possível então, a redação do trabalho final sobre o tema pesquisado.

\subsection{O USO DO LAUDO MÉDICO NA ESCOLA}

Após apresentação da pesquisa e ser solicitado que as entrevistadas narrassem sobre seu cotidiano com o público-alvo da educação especial, ao serem questionadas sobre a função do laudo médico, a maioria das respostas perpassou pela falta de capacidade de diagnosticar o aluno público-alvo da educação especial, conforme destacado abaixo:

Eu não posso trabalhar em cima do meu achismo que eu enquanto experiente, eu acho. Eu não vou dizer que eu tenho certeza, porque eu não posso dizer isso. [...] Mas é o médico que tem condições legais e me passar aqui. [...] Às vezes eu estou forçando uma coisa na criança que ela não tem condição de me dar essa resposta, por conta da deficiência (CLÁUDIA Entrevista concedida a Luana Leal Ribeiro em 07/10/2016).

A gente não vai taxar a criança disso ou daquilo, porque nós não podemos fazer isso, né?! Nós não temos formação específica. Não somos médicos e não podemos fazer assim (LAURA - Entrevista concedida a Luana Leal Ribeiro em 13/09/2016).

Professor não tem que diagnosticar. Professor tem que perceber e encaminhar aquela mãe, porque eles levam a palavra do professor como ferro e fogo. Então, nós temos esse cuidado, por isso que a gente faz essa triagem, damos as dicas aos pais, porque quem tem que perceber, quem tem que diagnosticar é uma equipe médica, até mesmo pra passar o laudo (BIANCA - Entrevista concedida a Luana Leal Ribeiro em 07/10/2016).

Diante das respostas, foi possível identificar que os professores não se sentem responsáveis e autônomos para organizar os critérios que definem quais seriam os alunos que poderiam ter acesso ao AEE. Outro ponto referiu-se ao questionamento sobre como acontece a identificação e o encaminhamento para atendimento no $\mathrm{AEE}$ dos alunos que não tinha declarada deficiência no ato da matrícula, mas que apresentavam limitações no desenvolvimento na sala de aula regular. De acordo com as entrevistadas:

Se o professor perceber, fala comigo e eu chamo a mãe. Falo sobre a dificuldade ou o comportamento que não está adequado e peço pra procurar e conversar com um pediatra e mando um relatório da escola, porque chegando lá, não vai saber conversar e podem dizer que a mãe está inventando coisa. [...] A gente fica aguardando o parecer da médica e a 
médica geralmente encaminha pro neuro e aí é com ele (JOANA - Entrevista concedida a Luana Leal Ribeiro em 23/09/2016).

O professor, principalmente no primeiro ano, chama atenção do professor porque ela começa a comparar e conversa comigo ou até chama a mãe e depois conversa comigo (CLÁUDIA - Entrevista concedida a Luana Leal Ribeiro em 07/10/2016).

Aí a gente começa investigando, chamando a professora da sala de recurso e chamamos os pais (BIANCA - Entrevista concedida a Luana Leal Ribeiro em 07/10/2016).

Aí fica tudo por conta deles. Já não é mais comigo. Pela lógica, o laudo tem que chegar primeiro lá, na sala de recurso (MARIA - Entrevista concedida a Luana Leal Ribeiro em 13/09/2016).

De início é o professor que olha. Quando ele chega na sala, levou o primeiro mês, é o tempo que o professor consegue identificar. Aí eles entram em contato com a gente, pedindo pra gente olhar e fazer uma avaliação (LAURA - Entrevista concedida a Luana Leal Ribeiro em 13/09/2016).

Percebe-se que os alunos que apresentam alguma dificuldade no processo de ensinoaprendizagem são considerados como responsabilidade prioritariamente do professor da sala de recursos, eximindo os professores da sala regular de analisar e criar novas estratégias que possibilitassem o seu desenvolvimento, sem antes rotula-lo como possuidor de alguma patologia. Por sua vez, quando acontece esse encaminhamento para avaliação do professor do AEE, este também transfere para o âmbito médico a possibilidade de diagnosticar com exatidão e controlar a possível patologia. Segundo Collares e Moysés (1994), os professores que deveriam ser os responsáveis por analisar os problemas educacionais, ao adotar uma postura acrítica, apenas encaminham os alunos aos especialistas da saúde. Por um lado, isto pode acalmar sua angústia, mas pelo outro, ao transferir a responsabilidade, desloca o eixo do coletivo para o particular. Assim, a instituição escolar "legitima suas ações e suas não-ações, pois o problema decorreria de doenças que impedem a criança de aprender" (COLLARES; MOYSÉS, 1994, p. 29).

O aluno com deficiência ainda é considerado de responsabilidade da educação especial, possivelmente pelo fato da oferta desta modalidade de atendimento educacional, no decorrer da história, estar vinculada a espaços segregados. Assim, o fator de sucesso dos alunos ficou ao cargo dos professores da sala de recursos e, raramente, dos professores da sala regular, que não veem o desenvolvimento do aluno incluído como sendo de sua responsabilidade (GLAT et al, 2006). Destarte, a autoridade médica, mesmo sem orientar os 
responsáveis e os professores, e sem ter nenhuma aproximação com a área educacional, detém o poder de dizer que aquela criança não está aprendendo por questões de cunho biológico. Com isso, anula-se a competência pedagógica, que deveria ser assumida pelo professor e não o é. Esse discurso produzido pelo médico passa a ser reproduzido pelo professor, que incorpora as explicações organicistas e reducionistas (BONADIO; MORI, 2013), dando ensejo a um ciclo no qual o aluno com deficiência vê-se limitado por todas aquelas pessoas que deveriam contribuir para o seu progresso.

As falas descritas ainda demonstram que, a partir de os primeiros sinais de suspeita dos profissionais da sala regular, a criança passa a ser considerada como possível possuidora de alguma patologia/disfunção que poderia justificar seu comportamento e/ou desenvolvimento na sala de aula. Assim, crianças diagnosticadas e rotuladas pela escola, podem ser isoladas dentro da própria sala de aula, por muros invisíveis, sendo encaminhadas, na primeira oportunidade, aos profissionais da saúde, na procura de legitimação de sua condição de doente (TEIXEIRA, 2007).

O encaminhamento dos alunos aos serviços de saúde visando à produção de um diagnóstico, sem que haja o olhar, a escuta e o diálogo, surge a partir da consideração de que o "fracasso escolar" é fruto de questões inerentes aos alunos. Christofari (2014) problematizou a medicalização dos modos de ser e de aprender, afirmando que há uma negação do verbo "estar" em detrimento do verbo "ser". Nesse sentido, o aluno que é hiperativo, é desinteressado, é lento, entre milhares de outros adjetivos, potencializa a concepção de estagnação e de imutabilidade.

Também foi questionado às docentes se o laudo médico era importante e se tinha função no delineamento das atividades no âmbito escolar. As respostas foram:

Tudo a partir do laudo se encaminha melhor, porque aí a gente tem como direcionar acompanhamentos médicos e o trabalho específico com aquela criança, é bem melhor! (BIANCA - Entrevista concedida a Luana Leal Ribeiro em 07/10/2016).

A importância do laudo é que ele te dá esse parâmetro de trabalho com a criança. Ele te indica a deficiência, a necessidade especial daquele aluno e em cima dessa necessidade, como que eu vou trabalhar, o que eu vou usar com ele. Então ele é muito importante. (CLÁUDIA - Entrevista concedida a Luana Leal Ribeiro em 07/10/2016). 


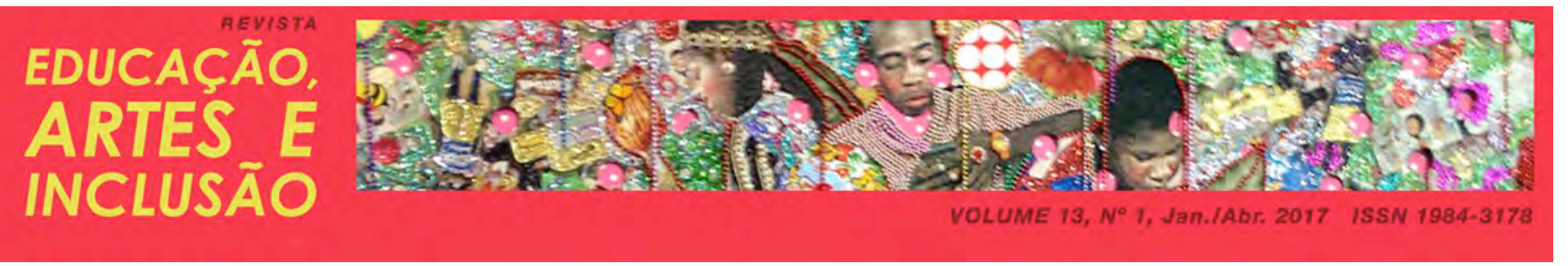

Claro! O laudo é necessário pra você saber qual é o problema da criança. A gente quer saber como reagir diante de determinada situação (JOANA Entrevista concedida a Luana Leal Ribeiro em 23/09/2016).

Ele tem função porque a gente precisa mostrar pra alguém que a criança tem o laudo. Tem que mostrar. [...] Ajuda? Ajuda! Eu não estou dizendo que não ajuda, mas, até o momento eu não tenho visto a necessidade de seguir o laudo pra conseguir atender o meu aluno especial não (LAURA - Entrevista concedida a Luana Leal Ribeiro em 13/09/2016).

Ele comprova pra gente saber o que a criança tem e se ela realmente precisa da sala de recursos, porque quando a gente sabe que a criança tem um problema, mas ela não tem laudo, nem nada que comprove aquilo, a gente sabe porque a gente vê! É visível na criança. E a gente lida com ela pra saber como que é o cognitivo dela, mas não tem nada que comprove (DALVA Entrevista concedida a Luana Leal Ribeiro em 25/10/2016).

O foco mesmo é trabalhar em cima da dificuldade da criança. Geralmente, de acordo com laudo. Dali tira a dificuldade dela. A gente trabalha com o que ele tem dificuldade. Eu vou muito na parte cognitiva, pra ajudar o professor na sala de aula (LUZIA - Entrevista concedida a Luana Leal Ribeiro em 25/10/2016).

Nunca vi, nem um! Quando eu quero saber, eu pergunto pra professora da sala de recursos. Pergunto se o aluno tem laudo e ela me diz (MARIA Entrevista concedida a Luana Leal Ribeiro em 13/09/2016).

Em mais de uma entrevista, encontramos a palavra "problema" atribuída aos alunos. Essa ideia reforça o estereótipo de que o único responsável pela falta de desenvolvimento na escola é o aluno, que possui um "problema" inerente, ratificando a transformação de uma questão que poderia ser pedagógica, em dificuldade individual.

É compreensível a defesa do uso do laudo como parâmetro para estabelecer os alunos que serão público-alvo da educação especial, pois se não houver critérios, todos os alunos que apresentem algum distúrbio no processo de ensino aprendizagem, serão considerados como sujeitos com disfunções biológicas. Porém, o uso do laudo como parâmetro para organização do trabalho pedagógico é nocivo à aprendizagem do aluno, pois o instrumento não aponta possibilidades e sim questões biológicas que comprometem de alguma forma essa aprendizagem. Assim, deve-se considerar que a existência não é o maior problema que permeia o laudo e sim a grande influência que este exerce no contexto educacional. Por mais que em algumas falas o laudo não tenha se apresentado como primordial, considerando prioritariamente as necessidades individuais, em outras, não excluíram o condicionamento da sua prática docente ao laudo clínico. 


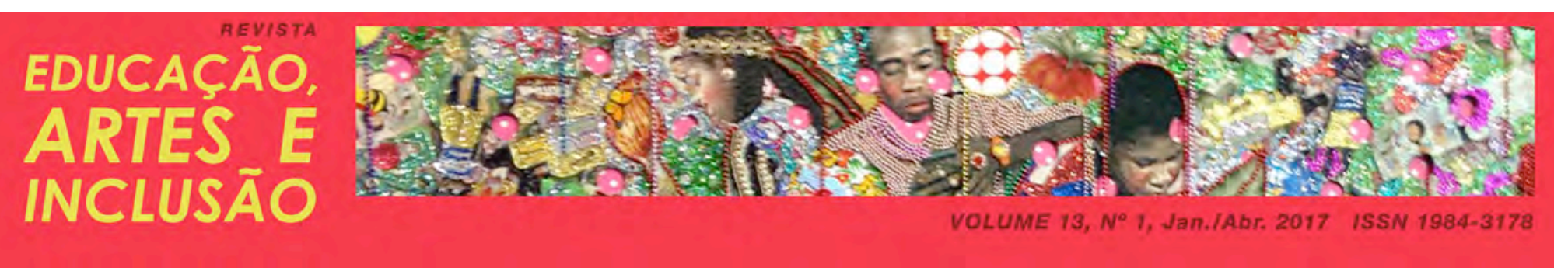

Na maioria das falas das entrevistadas, as mesmas afirmavam que o laudo tinha função de orientar a prática pedagógica. No entanto, contraditoriamente, quando indagadas da articulação entre o instrumento e as ações desenvolvidas nas salas, as mesmas afirmaram que o laudo servia apenas para determinar a limitação do aluno, ou seja, o parecer médico acaba se tornando condição negativa e não positiva para o desenvolvimento, criando incapacidades e não as desconstruindo.

Foi então, ainda, questionado se no laudo continha alguma informação de como o professor teria que lidar ou desenvolver as atividades com os alunos. Todas afirmaram que não, mas que pesquisavam a melhor forma de lidar com esse aluno.

Eu peço ajuda a professora da sala de recurso e entro pesquisando também, quais são as atividades que eu posso trabalhar com aquela criança, entendeu? [...] Então, a gente tem o laudo e cabe o meu papel de professor pesquisar, pra saber como lidar com ele (BIANCA - Entrevista concedida a Luana Leal Ribeiro em 07/10/2016).

A gente que já tem uma experiência começa a pesquisar, assiste muita coisa. A gente vai vendo o que essa criança precisa, o que ela é capaz de fazer (CLÁUDIA - Entrevista concedida a Luana Leal Ribeiro em 07/10/2016).

Uma professora afirmou que em uma dessas pesquisas descobriu um curso na modalidade à distância que chamou sua atenção.

Agora vou fazer um na parte de neurociência, porque a minha angústia é saber por que essa criança não aprende. $O$ que acontece nessa cabeça deles. E assim eu vou procurando fazer esses cursos de capacitação (CLÁUDIA Entrevista concedida a Luana Leal Ribeiro em 07/10/2016).

Nesse ponto, percebe-se que parece ser mais importante a justificativa do baixo rendimento escolar, que de certo modo, isenta a instituição escolar da responsabilidade de lidar com esse problema. Conforme apontou Teixeira (2007) o resultado dessa prática é a difusão acrítica e crescente das "patologias" que são consideradas como causadoras do "fracasso escolar". Com isso, a difusão de "patologias" mal definidas, descritas em diagnósticos vagos e imprecisos, rotulam sujeitos que não possuem qualquer disfunção biológica que interfira em seu aprendizado. 


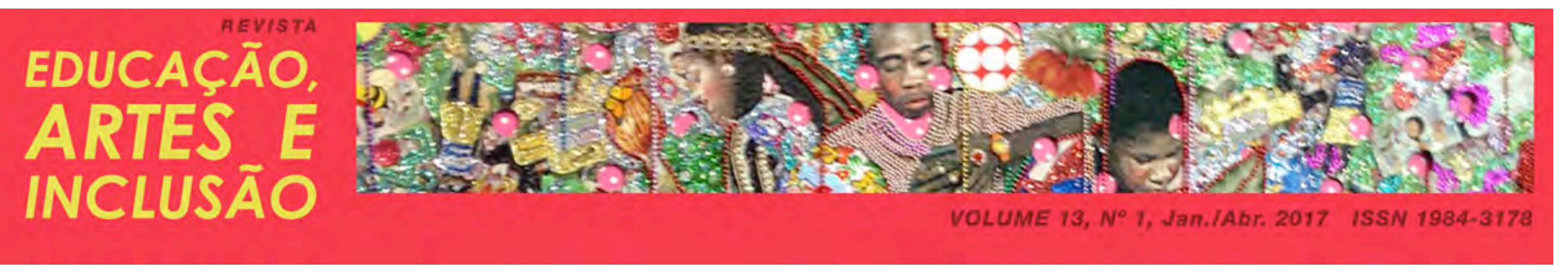

Mendoza (2014) afirmou que é nítida a subjugação do professor ao saber e à autoridade médica. A criança que foge à regra e apresenta comportamento diferenciado, desperta na escola um incômodo e faz com que os profissionais busquem soluções para justificar tais comportamentos. Ao perceberem esses comportamentos diferenciados, os profissionais do âmbito educacional buscam a partir de olhares patologizantes, meios para justificar e sanar os problemas identificados no contexto escolar (CAMIZÃO, 2016).

Questionadas sobre a possibilidade de o diagnóstico estar errado, as entrevistadas responderam que:

Mas aí... aí eu não posso... aí... eu tenho que me basear no que o laudo vem, porque eu vou, pedagogicamente até aqui (CLÁUDIA - Entrevista concedida a Luana Leal Ribeiro em 07/10/2016).

A moda agora é autista, né!? É igual qualquer é virose. Eu já vi caso de mudar o $\mathrm{CID}^{2}$. O médico disse que mudou! Eu nunca vi isso! Mudou na adolescência, porque geralmente nessa fase, eles sofrem transformações. Era esquizofrênico, agora tem outra síndrome (JOANA - Entrevista concedida a Luana Leal Ribeiro em 23/09/2016).

Tem uns que vem só com a sigla. Tem muitos laudos de autista, mas estão equivocados também. Você lembra da hiperatividade? Mau comportamento era hiperatividade. Falta de limite, era hiperatividade (LUZIA - Entrevista concedida a Luana Leal Ribeiro em 25/10/2016).

Para a compreensão especificamente da influência do diagnóstico em sua prática profissional, foi questionado se elas utilizavam e de que forma o laudo médico na criação de ações e estratégias com o público-alvo da educação especial. Segundo as profissionais

Não. Eu vou em cima da necessidade dele Eu olho a necessidade dele. A gente vê, né?! Você tá todo dia com a criança. É impossível você não ver. Então, a gente trabalha em cima disso, na necessidade dele (LAURA Entrevista concedida a Luana Leal Ribeiro em 13/09/2016).

Tem casos que é você lidar com a criança. Primeira vez que você trabalha com a criança, vai ver qual é a necessidade. Eu mesmo tenho duas crianças com transtorno opositor desafiador, que elas são diferentes uma da outra. Tenho alunos com o mesmo diagnóstico, mas trabalho com cada um de uma forma diferente. A gente acompanha o laudo? Sim, a gente tenta acompanhar

\footnotetext{
${ }^{2}$ Classificação Internacional de Doenças - CID.
} 
o laudo, mas primeiramente, a gente vê qual é a necessidade dessa criança (DALVA - Entrevista concedida a Luana Leal Ribeiro em 25/10/2016).

O laudo é um documento que a gente tem se a supervisora chegar tem o laudo. Na prática é pra ter a documentação pra dizer qual é o problema da criança (JOANA - Entrevista concedida a Luana Leal Ribeiro em 23/09/2016).

Eu olho o laudo, mas eu abro o leque com ele. Começo a investigar a criança [...]. O laudo em si é burocrático. Eu pelos anos que tenho, sinto assim: é uma maneira de colocar na sala de recursos, mas sendo que tem laudo que não dá muita abertura pra gente. Tem que conhecer o aluno e vê o que vai trabalhar com o aluno (LUZIA - Entrevista concedida a Luana Leal Ribeiro em 25/10/2016).

Essas respostas deixaram claro que na prática o laudo médico configurou-se muito mais uma questão burocrática do que um instrumento que norteia a prática profissional. A maioria dos professores, mesmo ressaltando a importância do laudo para identificar o "problema" do aluno, não conseguiu expressar com clareza a utilização do documento no fazer profissional. Durante as entrevistas, apesar de indagadas por mais de uma vez, elas não expuseram em momento algum, uma estratégia criada de acordo com a descrição da deficiência. Nesse sentido, pode-se dizer que a exigência do laudo, portanto, acaba se configurando um instrumento que na prática, além de limitar a oferta do AEE, não garante que ações inclusivas sejam efetivadas.

Assim, ao considerar o diagnóstico como primordial para nortear ações desenvolvidas no AEE, os professores continuam sem elementos plausíveis para sua atuação, pois não há, junto ao laudo, prescrições no modo de atuar junto à criança com deficiência na educação especial. Portanto, observou-se que existe um "não saber" o que fazer com os alunos públicoalvo da educação especial. Com a categorização dos discentes a partir do laudo, esperava-se que a avaliação médica possibilitasse o direcionamento do tipo de "ajuda" que deveriam receber. Porém, “a definição e a conceituação do tipo de deficiência não são dinâmicas, não interferem no atendimento dessa criança, estigmatizam como incapaz e não têm modificado a forma de atendimento na escola" (TARTUCI et al, 2014, p. 78). Até mesmo, porque de acordo com as falas, nem sempre há descrição da deficiência, sendo indicado somente o código de acordo com a CID. A partir disso, constatou-se que os profissionais do âmbito escolar podem passar a utilizar o laudo médico como respaldo pelo baixo ou não aprendizado 


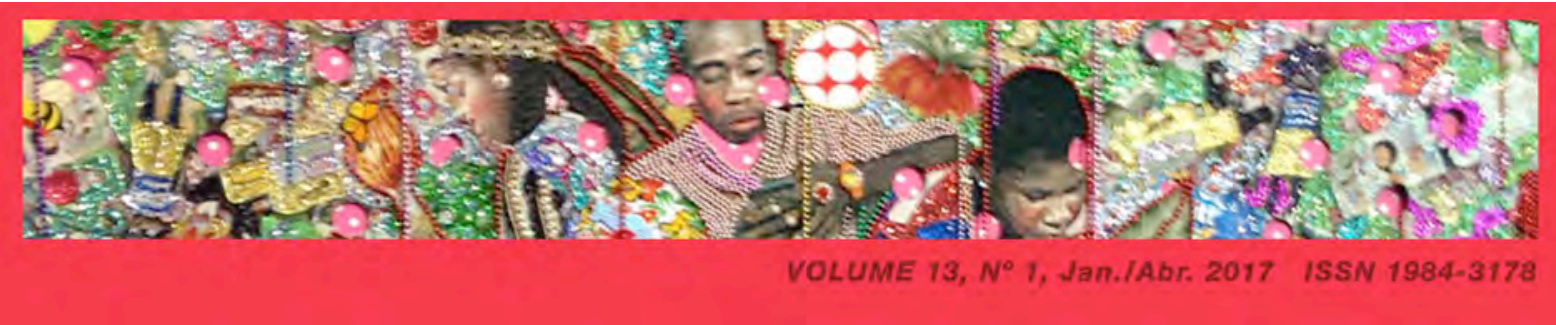

esperado dos alunos com deficiência, prevalecendo às práticas de integração escolar em detrimento das de inclusão (FRANCO, 2012).

Cabe destacar que a efetiva inclusão desses alunos no âmbito escolar, ultrapassa o fato de sua inserção na sala regular, sem que haja preocupação com a acessibilidade no acesso às informações no processo de escolarização. Há a necessidade de modificação na forma como o currículo é ofertado aos alunos e das possibilidades que lhes são atribuídas para demonstrar seu aprendizado. Um dos caminhos para modificação desse cenário pode acontecer por meio do Desenho Universal para Aprendizagem que visa à criação de ambientes acessíveis para o maior número possível de pessoas, independente da sua deficiência. Também é necessário que haja discussão acerca do conteúdo elencado no currículo e a possibilidade de acesso a esse conteúdo, buscando identificar se o público-alvo da educação especial está representado nesse currículo (GABEL; CONNOR, 2009).

A responsabilização dos educadores da modalidade especial no que diz respeito ao ingresso no atendimento educacional especializado, através do enfoque na avaliação pedagógica, fortaleceria a responsabilidade que esses atores teriam no processo de diagnóstico inicial para acesso à sala de recursos (BAPTISTA, 2011). Porém, ficou claro que os profissionais não sentem que são os responsáveis por esse encaminhamento aos serviços da educação especial. Há de se concordar, que talvez esses atores realmente não estejam preparados para construção dessa prática, em vistas do histórico da vinculação dessa modalidade educacional aos serviços do âmbito médico. Portanto, a autonomia dos professores, deverá constituir-se em um processo objetivando que sejam ressaltados os aspectos pedagógicos na construção de uma avaliação inicial contextualizada e pautada nos cenários em que esse aluno se insere.

\section{CONSIDERAÇÕES}

O trabalho articulado entre professores da educação na modalidade especial e regular, assim como o trabalho vinculado com as famílias, antes do repasse imediato ao âmbito clínico poderia ser considerado uma alternativa que visaria à construção de olhares sobre o aluno desvinculado de estigmas, geralmente ocasionados nos primeiros sinais de desvio. A identificação do público-alvo que terá acesso ao AEE, principalmente os alunos com 
deficiências não sensoriais, como a intelectual, não podem ser pautados no que ele apresenta como falta e em suas dificuldades. Deve ser ressaltado que nesse processo, o professor não pode ser o único responsabilizado pela falta de autoridade pedagógica no que tange aos alunos da educação especial, justamente pela sua submissão ao âmbito da medicina. A formação dos profissionais da educação deveria prepara-los para ensinar os alunos, considerando suas particularidades, potencialidades e subjetividades, compreendendo os discentes como sujeitos capazes de aprender, apesar de suas dificuldades. Portanto, cabem ações que vão desmistificar essa subordinação e dar maior autonomia a esses profissionais por meio da qualificação, de práticas reflexivas e do trabalho conjunto com os demais atores que permeiam os contextos vivenciados pelos alunos.

Após a explanação e a problematização dos dados supracitados, apreendeu-se que os laudos têm sido confeccionados de forma fragilizada, descontextualizados da realidade social a que pertencem os alunos, sendo fechados e não explicativos, configurando-se como um documento que tende a profetizar um processo de ensino-aprendizagem negativo, devido à presença da disfunção inata ao aluno. Portanto, o uso do laudo no ambiente escolar tem se demonstrado como uma barreira que impede o acesso dos discentes ao AEE, não podendo ser identificado nas falas das profissionais, subsídios pensados a partir do laudo, no desenvolvimento de práticas e estratégias de intervenção na oferta de escolarização desses sujeitos. Assim, a ênfase no diagnóstico pode trilhar percursos que serão determinantes no histórico escolar dos alunos público-alvo da educação especial, que, pautados nessa perspectiva, tendem a permanecer na escola, estigmatizados e sem grandes perspectivas de aprendizagem, restringindo assim, suas potencialidades de desenvolvimento no âmbito escolar.

A discussão sobre a organização de um currículo flexível e acessível a todos os alunos torna-se urgente, com vistas a possibilitar meios de aprendizagem adaptados e que possam vir a estimular todo alunado por meio de atividades desafiantes. Para tal, cabe discutir e divulgar a temática com os profissionais da educação desde seu processo de formação inicial, não se restringindo aos que atuam somente na modalidade especial. Busca-se, assim, reforçar a autonomia pedagógica desses sujeitos no processo de ensino-aprendizagem de alunos, possibilitando a flexibilidade desses profissionais em organizar sua intervenção pedagógica com estratégias diversificadas de modo que possibilite estimular a motivação e apreensão dos 


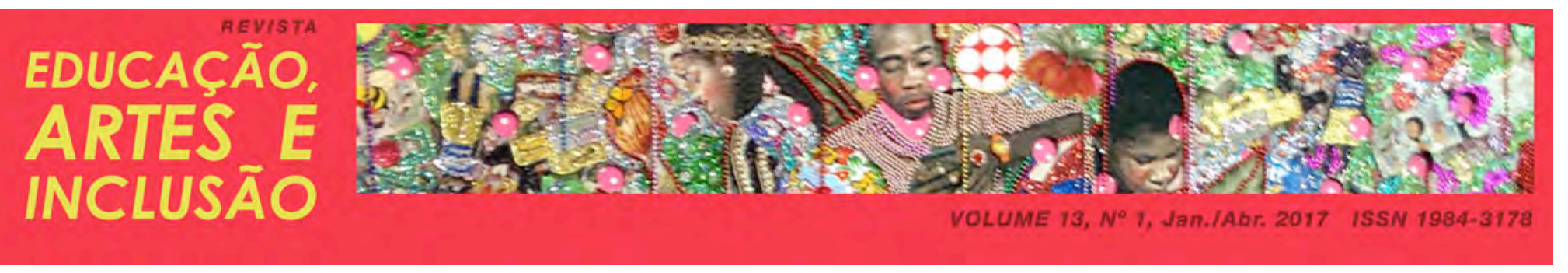

conteúdos, possibilitando a vivência de experiências segundo suas necessidades e possibilidades de ultrapassar as barreiras impostas por um cenário educacional ainda não inclusivo.

\section{REFERÊNCIAS}

ARANHA, Maria Salete Fábio. Paradigmas da relação da sociedade com as pessoas com deficiência. Revista do Ministério Público do Trabalho, Ano XI, nº 21, p. 160-173. Março, 2001. Disponível em $<$ http://www.adiron.com.br/arquivos/paradigmas.pdf $>$. Acesso em 22/07/2016.

BAPTISTA, Claudio Roberto. Ação pedagógica e educação especial: a sala de recursos como prioridade na oferta de serviços especializados. Rev. bras. educ. espec. vol.17 no.spe1 Marília May/Aug. 2011. Disponível em: < http://www.scielo.br/scielo.php?script=sci_arttext\&pid=S141365382011000400006> Acesso em: 02/02/2017.

BOGDAN, Roberto C. BIKLEN, Sari Knopp. Investigação qualitativa em educação - uma introdução à teoria e aos métodos. Porto Editora. Porto/Portugal, 1994.

BONADIO, Rosana Aparecida Albuquerque; MORI, Nerli Nonato Ribeiro. Transtorno de déficit de atenção/hiperatividade: diagnóstico da prática pedagógica [online]. Maringá: Eduem, 2013, pp. 233242. Disponível em: < http://books.scielo.org/id/963vf/pdf/bonadio-9788576286578.pdf > Acesso em: $02 / 02 / 2017$.

BRASIL. Diretrizes Nacionais para Educação Especial na Educação Básica. Brasília: MEC/SEESP, 2001. Disponível em: < http://portal.mec.gov.br/seesp/arquivos/pdf/diretrizes.pdf>. Acesso em: 14/07/2016.

BRASIL. Nota técnica de $\mathbf{n}^{\mathbf{0}}$ 4/2014. Ministério da Educação. Secretaria de Educação Continuada, Alfabetização, Diversidade e Inclusão. Diretoria de Políticas de Educação Especial. 2014. Disponível em: $<$ http://portal.mec.gov.br/index.php?option $=$ com_docman\&view $=$ download\&alias $=15898$ nott04-secadi-dpee-23012014\&category_slug=julho-2014-pdf\&Itemid=30192>. Acesso em $24 / 04 / 2017$.

BRASIL. Política Nacional de Educação Especial na Perspectiva da Educação Inclusiva. Brasília: MEC/SEESP, 2008. Disponível em: <http://portal.mec.gov.br/seesp/arquivos/pdf/politica.pdf $>$ Acesso em: 16/07/2016.

CAMIZÃO, Amanda Costa. Conhecimentos, concepções e práticas de professores de educação especial: o modelo médico-psicológico ainda vigora? Dissertação (Mestrado em Educação) Universidade Federal do Espírito Santo, Centro de Educação. 180 f. Vitória, 2016. Disponível em: < http://portais4.ufes.br/posgrad/teses/tese_10564_Disserta\%E7\%E3o\%20AmandaFinal.pdf $>$ Acesso em: 05/02/2017.

CAMPOS DOS GOYTACAZES. (Município Rio de Janeiro). Resolução/SME nº 01/12 do dia 26 de dezembro de 2012. 


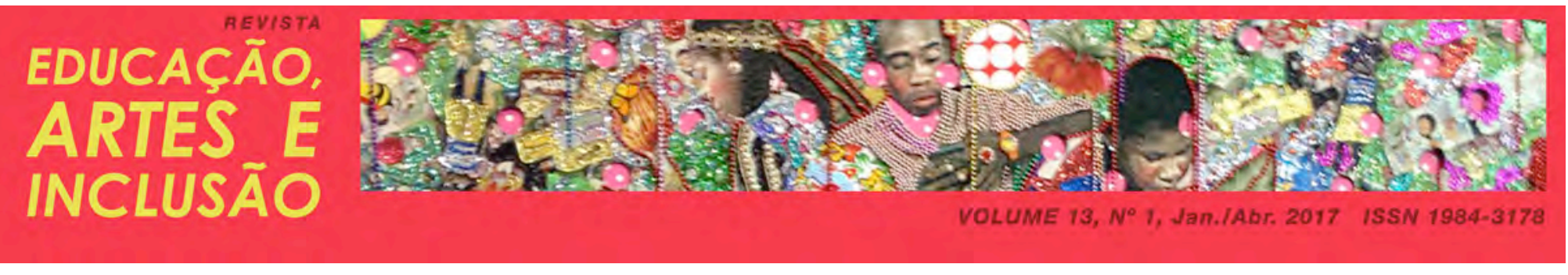

CHRISTOFARI, A. C. Modos de ser e de aprender na escola: medicalização (in)visível?. 2014. 173 f. Tese (Doutorado em Educação) - Programa de Pós-Graduação em Educação, Universidade Federal do Rio Grande do Sul, Porto Alegre, 2014.

COLLARES, C. A. L.; MOYSÉS, Maria Aparecida Affonso. A transformação do espaço pedagógico em espaço clínico (a patologização da educação). Série Ideias, n. 23. São Paulo, FDE, 1994, p. 25-31. Disponível em: $<$ http://www.crmariocovas.sp.gov.br/pdf/ideias_23_p025-031_c.pdf > Acesso em: 02/02/2017.

DINIZ, D. O que é deficiência? Coleção Primeiros Passos. p. 324. Brasiliense. São Paulo, 2007.

FOUCAULT, Michel. As palavras e as coisas: uma arqueologia das ciências humanas. Michel Foucault: tradução de Salma Tannus Muchail. $-8^{\mathrm{a}}$ ed. - Coleção Tópicos. Martins Fontes. São Paulo, 2000.

FRANCO, Marco Antonio Melo. O discurso médico e a prática pedagógica no ensino da criança com paralisia cerebral: a importância de se retomar o diálogo entre saúde e educação para a constituição de novas práticas. Paidéia r. do cur. de ped. da Fac. de Ci. Hum., Soc. e da Saú., Univ. Fumec Belo Horizonte Ano 9 n.13 p. 157-178 jul./dez. 2012

GABEL, S. L.; CONNOR, D. J. Theorizing disability: Implications and applications for social justice in education. In W. Ayres, T. Quinn, \& D. Stovall (Eds.), Handbook of social justice in education (pp. 377-399). Routledge. New York, 2009. Disponível em: <

https://www.academia.edu/261643/Theorizing_disability_Implications_and_applications_for_social_j ustice_in_education>. Acesso em: 25/04/2017.

GARCIA, Rosalba Maria Cardoso. Políticas para a Educação Especial e as formas organizativas do trabalho pedagógico. Rev. Bras. Ed. Esp., Set.-Dez., v.12, n.3, p.299-316. Marília, 2006.

GARRIDO, Juliana, Questionando a medicalização de crianças com dificuldade de escolarização - o estado da arte da produção acadêmica sobre o tema nas áreas de educação, medicina e psicologia. 2010. FCM/UNICAMP. Campinas, 2010.

GIL, Antonio Carlos. Métodos e técnicas de pesquisa social / Antonio Carlos Gil. - 6. Ed. - São Paulo: Atlas, 2008.

GLAT, Rosana; PLETSCH, Márcia Denise. Estratégias educacionais diferenciadas para alunos com necessidades especiais./ Rosana Glat, Márcia Denise Pletsch. - Rio de Janeiro: EdUERJ, 2013. $200 \mathrm{p}$.

GLAT, Rosana; PLETSCH, Márcia Denise; FONTES, Rejane de S. Educação inclusiva \& educação especial: propostas que se complementam no contexto da escola aberta à diversidade. Santa Maria, v. 32, n. 2, p. 343-356, 2007. Disponível em: <http://www.ufsm.br/ce/revista > Acesso em: 07/01/2016.

GLAT, Rosana; SANTOS, Mônica Pereira dos; SOUSA, Luciane Porto Frazão de; XAVIER, Kátia Regina. Formação de professores na educação inclusiva: diretrizes políticas e resultados de pesquisas. Publicado em Anais do XIII ENDIPE- XIII Encontro Nacional de Didática e Prática de Ensino Recife - Pernambuco - 2006. Disponível em: < /http://www.lapeade.com.br/publicacoes/artigos/ENDIPE\%202006.pdf $>$ Acesso em: 02/02/2017.

HARLOS, Franco Ezequiel. Sociologia da deficiência : vozes por significados e práticas (mais) inclusivas. 200 f. Dissertação (Mestrado) -- Universidade Federal de São Carlos. São Carlos, 2012. 


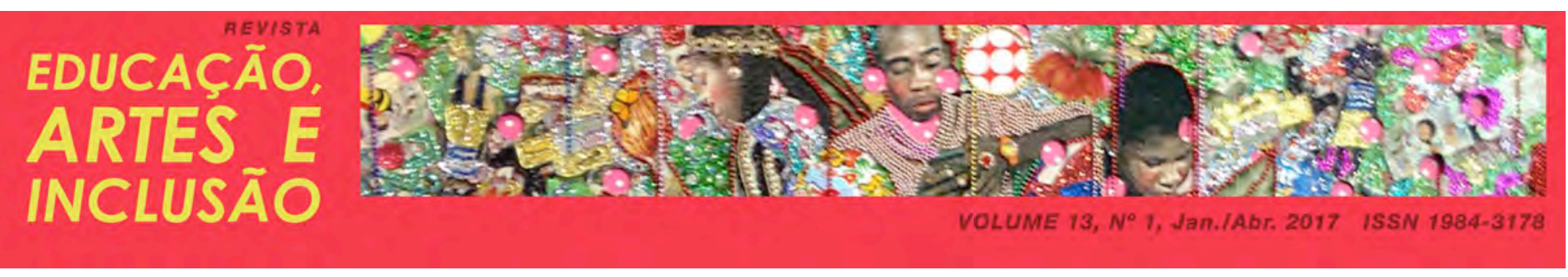

JANNUZZI, Gilberta S. de M. A educação do deficiente no Brasil: dos primórdios ao início do século XXI / Gilberta S. de M. Jannuzzi. - 3. Ed. Ver. - Campinas, SP: Autores Associados, 2012.

LOURENÇO, Érika. Conceitos e práticas para refletir sobre a educação inclusiva. Série Cadernos da Diversidade. Belo Horizonte: Autêntica Editora; Ouro Preto, MG: UFOP, 2010.

MARCONI, Maria de Andrade; LAKATOS, Eva Maria. Fundamentos de metodologia científica. 5. ed. São Paulo: Atlas 2003.

MENDES, E. G. A radicalização do debate sobre inclusão escolar no Brasil. Revista Brasileira de Educação v. 11 n. 33 set./dez. 2006. Disponível em:

$<$ http://www.scielo.br/pdf/rbedu/v11n33/a02v1133.pdf $>$ Acesso em: 07/01/2016

MENDOZA, Ana Maria Tejada. Escolarização em diagnóstico: crianças em concreto. Dissertação (Mestrado - Programa de Pós Graduação em Psicologia). - Instituto de Psicologia da Universidade de São Paulo. 200f. São Paulo, 2014. Disponível em: <

http://www.teses.usp.br/teses/disponiveis/47/47131/tde-12112014-

114038/publico/mendonza_corrigida.pdf> Acesso em: 02/02/2017.

PADILHA, Caio Augusto Toledo. Educação e inclusão no Brasil (1985-2010). 2014. $391 \mathrm{f}$.

Dissertação (Mestrado) - Faculdade de Educação da Universidade Estadual de Campinas. Campinas, 2014.

PESSOTTI, Isaías. Deficiência mental: da superstição à ciência. 204 p. Marília: ABPEE, 2012.

PICCOLO, Gustavo Martins. Contribuições a um pensar sociológico sobre a deficiência. $231 \mathrm{f}$. Tese (Doutorado) - Universidade Federal de São Carlos. São Carlos, 2012.

PLETSCH, Márcia Denise. Repensando a inclusão escolar: diretrizes políticas, práticas curriculares e deficiência intelectual. Rio de Janeiro: Nau: Edur, 2010.

TARTUCI, D.; FLORES, M. M. L.; BERGAMASCHI, E. M. M.; DEUS; D. C. M. Avaliação e o Atendimento Educacional Especializado. Poíeses Pedagógica. Catalão - GO, v. 12, n. 1, p. 67-93, jan/jun. 2014.

TEIXEIRA, Ynayah Souza de Araújo. O enfrentamento da medicalização pelo trabalho pedagógico. Dissertação (Mestrado ) Universidade Estadual de Campinas. Faculdade de Ciências Médicas. Campinas, SP, 2008. Disponível em: <

http://www.bibliotecadigital.unicamp.br/zeus/auth.php?back=http://www.bibliotecadigital.unicamp.br/ document $/$ code $=$ vtls000440405\&go $=x \& \operatorname{code}=x \&$ unit $=x>$ Acesso em: 02/02/2017.

TEZZARI, Mauren Lúcia. Educação especial e ação docente: da medicina à educação. 2009. 235 f. Tese (Doutorado) - Programa de Pós-graduação em Educação da Faculdade de Educação da Universidade Federal do Rio Grande do Sul. Porto Alegre, 2009.

Recebido em 25 de março de 2017 Aprovado em 29 de março de 2017 